\title{
Endovascular Treatment of an Iatrogenic Vertebral Arteriovenous Fistula Presented with Weight Loss
}

\author{
Junji Uno, M.D., Ph.D., Katsuharu Kameda, M.D., Ph.D., Shota Yoshida, M.D., \\ Ryosuke Otsuj, M.D., Nice Ren, M.D., Shintaro Nagaoka, M.D., Kazushi Maeda, M.D., \\ Yoshiaki IkAI, M.D., Ph.D., and Hidefuku Gi, M.D., Ph.D.
}

\begin{abstract}
Summary: Objective: Vertebral arteriovenous fistulas (VAVFs) are uncommon lesions and are caused by traumatic or spontaneous origin. Tinnitus or bruit is the most common symptom of VAVFs, but there are no reported cases that weight loss is a chief complaint.

Case presentation: A 26-year-old man presented with weight loss and a supraclavicular pulsatile mass. Seven years prior to this admission, his right jugular vein had been catheterized for treatment of Guillain-Barré syndrome. Digital subtraction angiography showed a high-flow VAVF between segment V1 of the right vertebral artery and the paravertebral venous plexus. The fistula was successfully trapped internally by using detachable coils. The postprocedural course was good, and there has been no recurrence during the 31 months of follow-up. The body weight of the patient recovered by $10 \mathrm{~kg}$ in the year after treatment. It is considered that the mechanisms of the weight loss in VAVF are similar to the mechanisms of the weight loss which is one of the complications in the cases of heart failure.

Conclusion: Endovascular treatment may be considered the treatment of choice for VAVFs.
\end{abstract}

\author{
Key words: \\ - arteriovenous fistula \\ - central venous line \\ - detachable coil \\ - weight loss
}

Surg Cereb Stroke

(Jpn) 46: 155-158, 2018

\section{Introduction}

Vertebral arteriovenous fistulas (VAVFs) are abnormal connections between the vertebral artery and neighboring veins ${ }^{8)}$. They are rare lesions and are caused by a traumatic or spontaneous origin. The known causes of these fistulas are penetrating or blunt neck injuries, or they may be of iatrogenic origin ${ }^{2)}$; for example, they have been reported to be caused by the sequelae of direct puncture of the carotid or vertebral artery, central line insertion, or complications of cervical spine surgery ${ }^{4}$. Here, we report a case of an iatrogenic VAVF complicating central line insertion that was treated successfully using endovascular techniques. There are no reported cases that weight loss is a chief complaint.

\section{Case presentation}

A 26-year-old man presented with abnormal weight loss (16 kg weight loss [18.8\%] in one year) and a supraclavicular pulsatile mass. Body Mass Index has changed from 24.8 to
20.2 in one year. Neurologic examination yielded normal results. Auscultation demonstrated a supraclavicular bruit. Seven years prior to this admission to our hospital, the right jugular vein was catheterized for treatment of Guillain-Barré syndrome during hospitalization. The patient had no history of trauma or operation to the neck or any family history of hereditary disease and no medical diseases causing weight loss. There were no findings of heart failure. Blood test findings showing nutritional status were within the normal range. Magnetic resonance imaging of the brain showed no abnormal findings. Digital subtraction angiography demonstrated a high-flow VAVF between segment V1 of the right vertebral artery (VA) and the paravertebral venous plexus (Fig. 1). The fistula had a single orifice about $7 \mathrm{~mm}$ in size. The right VA was dilated proximal to the fistula, and its distal portion was slightly opacified. The blood supply from the left VA to posterior circulation was accounted sufficient. The fistula was not fed by backward flow from the left VA (Fig. 2). A balloon occlusion test of the right VA, which was 


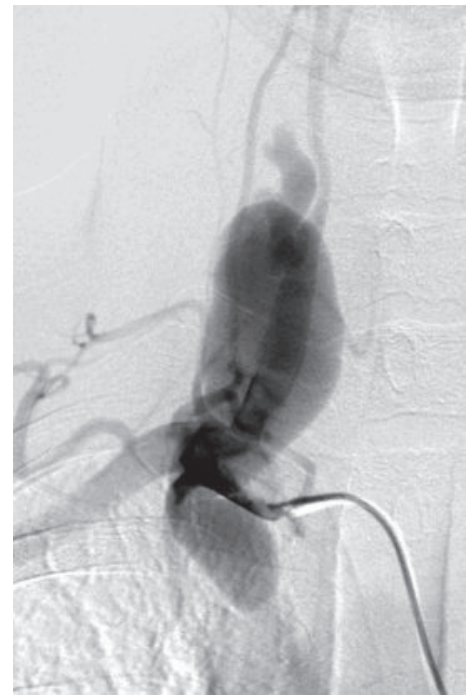

Fig. 1 A right vertebral artery angiogram showing high-flow vertebral arteriovenous fistula between segment $\mathrm{V} 1$ of the right vertebral artery and the dilated paravertebral venous plexus.

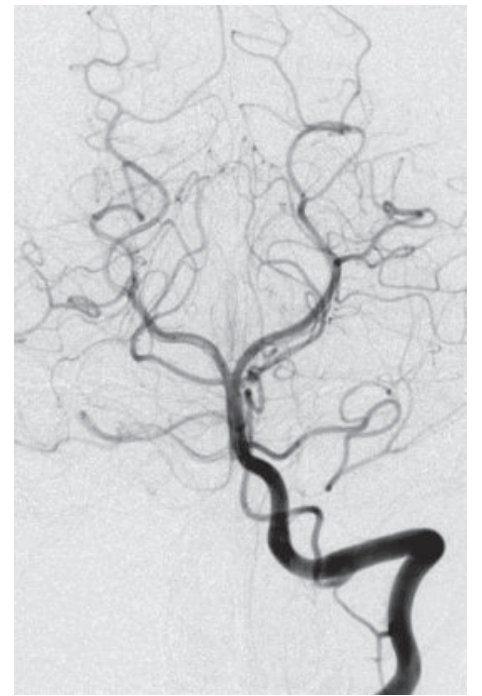

Fig. 2 A left vertebral artery angiogram showing that the blood supply from the left vertebral artery to posterior circulation was sufficient, and that the fistula was not fed by backward flow from the left vertebral artery. occluded for 30 minutes with a non-detachable balloon at the shunt point, was well tolerated. We decided to perform intravascular occlusion of the right VA including the fistula. Under systemic heparinization and local anesthesia, a 7-French balloon guiding catheter (Optimo; Tokai Medical Products Inc., Kasugai, Japan) was advanced into segment V1 of the right VA. A microcatheter (Excelsior 1018; Stryker Neurovascular, Cork, Ireland) was maneuvered into the right VA in the portion just distal to the fistula. Detachable coils were delivered to occlude the right VA from the portion distal to the fistula to the portion proximal to the fistula, including the orifice, and flow was controlled by inflating the balloon of a guiding catheter. Postoperative angiograms confirmed complete occlusion of the fistula (Fig. 3). The vascular bruit stopped immediately after the procedure. The patient had an unremarkable postprocedural course. During the 31 months of follow-up, he had no symptoms and no lesions were noted in MRI studies (Fig. 4). The body weight of the patient recovered by $10 \mathrm{~kg}$ in the year after treatment.

\section{Discussion}

Arteriovenous fistulas are more common in the VA, which is surrounded by plexiform veins along its course than other cervical vessels $^{8)}$. The fistulas are of traumatic origin in 41$60 \%$ cases and of spontaneous origin in 40-59\% cases $^{24) 8)}$. Traumatic VAVFs are caused by penetrating neck injuries and fracture of the cervical spine or may have iatrogenic causes $^{28)}$. False puncture of the VA when inserting the central venous catheter into the jugular vein is a well-known iatrogenic cause ${ }^{6}$. Similarly, VA injuries during cervical spine surgery are also one of the iatrogenic causes. Among traumatic VAVFs, most iatrogenic VAVFs are located in segment $\mathrm{V1}^{8)}$. This segment ascends vertically from the subclavian artery and the anterior scalene muscle. A single vertebral vein accompanies the VA in its short first portion, posterior to the artery, to drain into the posterior aspect of the brachiocephalic vein ${ }^{3)}$. Tinnitus or bruit is the most common symptom of VAVFs. These fistulas can also result in brain and spinal cord dysfunction and massive hemorrhage $^{4)}$. There are no reported cases that weight loss was a chief complaint. The body weight of the patient in the present study recovered by $10 \mathrm{~kg}$ in the year after treatment. Although the causal relationship between VAVF and weight loss is uncertain, it is considered that the mechanisms of the weight loss in VAVF are related to heart failure. Arteriovenous fistula is the second most common cause of high-output heart failure ${ }^{5)}$. Weight loss was clinically documented in $11 \%$ cases of heart failure ${ }^{9}$. The detailed mechanisms of weight loss associated with heart failure have not been reported yet. Patients with heart failure were shown to have lower blood flow in the superior and inferior mesenteric arteries and in the celiac trunk and greater abdominal discom- 


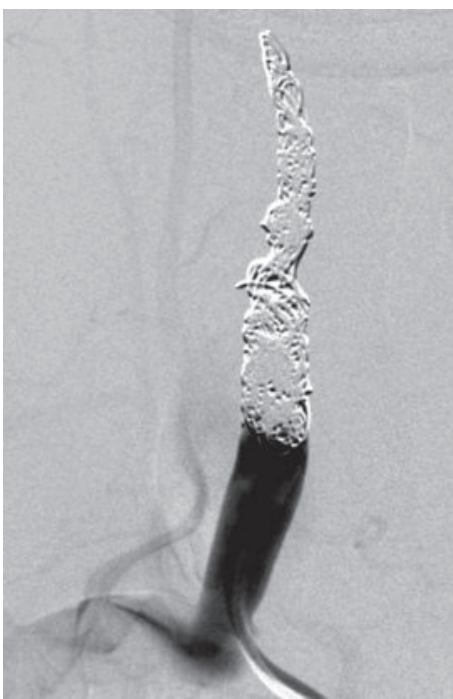

Fig. 3 Right vertebral artery injection after embolization. Occlusion of the fistula is observed.

fort than controls ${ }^{7)}$. These findings are thought to lead to weight loss. In our case, no findings indicated heart failure, but in asymptomatic patients like our patient, a high cardiac output state may occur ${ }^{1)}$.

Although surgical treatment is an option, endovascular treatment is a safe, less invasive, and reliable treatment for VAVFs $^{8) 10)}$. Occlusion of the fistula with preservation of the VA is considered to be the ideal treatment, but it is difficult to perform this treatment for fistulas with large orifices. In the present case, the fistula had a large orifice and there was little flow to the portion of the right VA distal to the fistula. Further, a balloon Matas test of the right VA showed negative results. From these findings, we decided on internal trapping of the right VA. Halbach et al. pointed out that patients with long-standing fistulas may be at risk of developing neurologic deficits if the fistulas are abruptly occluded. They postulated that the chronically ischemic cerebral vasculature is unable to regulate cerebral blood flow once normal perfusion is reestablished, and that this break-through phenomenon may cause new neurologic symptoms ${ }^{4)}$. Although steal phenomenon is not observed, internal trapping using endovascular techniques may be safe for treating longstanding high-flow VAVFs, such as the one in our case.

\section{Conclusions}

We treated a 26-year-old man who presented with weight loss and a supraclavicular pulsatile mass, which was diagnosed to be a VAVF, a rare clinical entity. Internal trapping

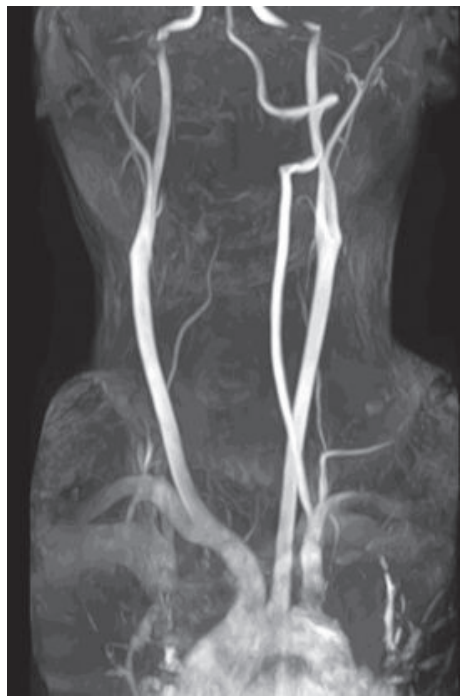

Fig. 4 During the 31 months of follow-up, magnetic resonance imaging showed no recurrence of the fistula.

with detachable coil embolization was successful in the present case, and the patient recovered well. Thus, internal trapping with endovascular techniques may be safer than surgery for treating long-standing high-flow VAVF, such as the one in our case. The body weight of the patient in the present study recovered by $10 \mathrm{~kg}$ in the year after treatment.

\section{Declaration of conflicts of interest}

None of the authors or co-authors have any conflict of interest to declare.

\section{References}

1) Aitken E, Kerr D, Geddes C, et al: Cardiovascular changes occurring with occlusion of a mature arteriovenous fistula. $J$ Vasc Access 16: 459-466, 2015

2) Beaujeux RL, Reizine DC, Casasco A, et al: Endovascular treatment of vertebral arteriovenous fistula. Radiology 183: 361367, 1992

3) González A, Mayol A, Gil-Peralta A, et al: Endovascular stentgraft treatment of an iatrogenic vertebral arteriovenous fistula. Neuroradiology 43: 784-786, 2001

4) Halbach VV, Higashida RT, Hieshima GB: Treatment of vertebral arteriovenous fistulas. AJR Am J Roentgenol 150: 405-412, 1988

5) Reddy YN, Melenovsky V, Redfield MM, et al: High-output heart failure: a 15-year experience. J Am Coll Cardiol 68: 473-482, 2016

6) Ricolfi F, Valiente E, Bodson F, et al: Arteriovenous fistulae complicating central venous catheterization: Value of endovascular treatment based on a series of seven cases. Intensive Care Medicine 21: 1043-1047, 1995

7) Sandek A, Swidsinski A, Schroedl W, et al: Intestinal blood flow 
in patients with chronic heart failure: a link with bacterial growth, gastrointestinal symptoms, and cachexia. J Am Coll Cardiol 64: 1092-1102, 2014

8) Vinchon M, Laurian C, George B, et al: Vertebral arteriovenous fistulas: a study of 49 cases and review of the literature. Cardiovasc Surg 2: 359-369, 1994
9) Williams BA: The clinical epidemiology of fatigue in newly diagnosed heart failure. BMC Cardiovasc Disord 17: 122, 2017

10) Yoshida S, Nakazawa K, Oda Y: Spontaneous vertebral arteriovenous fistula--case report. Neurol Med-Chir (Tokyo) 40: 211215,2000

\title{
体重減少を主訴とした医原性椎骨動静脈瘦の 1 例
}

\section{宇野 淳二, 亀田 勝治, 吉田 正太, 尾辻 亮介, 連 乃駿, 長岡慎太郎, 前田 一史, 伊飼 美明, 魏 秀復}

\author{
馬場記念病院 脳神経外科
}

目的：椎骨動静脈瘦 $(\mathrm{VAVF})$ はまれな病変であり, 原因として 外傷性または特発性が挙げられる。症状の多くは耳鳴りと血管雑 音であるが，体重減少を主訴とした例はいまだない．

症例：26歳, 男性. 体重減少と鎖骨上部の拍動性腫瘤を呈し た.この入院の 7 年前, 右䅡静脈は Guillain-Barré 症候群の治療の ためにカテーテルを挿入されていた，脳血管撮影では，右椎骨動 脈のV1 segment と傍脊柱静脈叢との間に高流量 VAVF が示され
た。瘻孔は, detachable coil を使用することにより, 右椎骨動脈 の internal trappingにて治療した。術後経過は良好であり，追跡 期間の 31 力月間に再発はなかった。治療後体重は 1 年間で $10 \mathrm{~kg}$ 増加した，体重減少と本疾患の因果関係は明らかでないが，心不 全患者の合併症の 1 つである体重減少と同様な機序が考えられる. 結論：血管内治療はVAVF の治療として，第一選択となり得る. 